\title{
Absence of Error-prone Repair in a Vibrio species
}

\author{
By JENNIFER A. THOMSON, ${ }^{*}$ MARIA E. C. BARROS $\ddagger$ \\ AND CHRISTIANE GIESEMANN \\ Department of Genetics, University of the Witwatersrand, 1 Jan Smuts Avenue, \\ Johannesburg 2001, South Africa
}

(Received 18 February 1985; revised 26 April 1985)

The effect of various DNA-damaging agents on a Vibrio species was investigated. The organism was readily mutable by $N$-methyl- $N^{\prime}$-nitro- $N$-nitrosoguanidine and mitomycin $\mathrm{C}$ but not by UV light. No Weigle reactivation of UV-irradiated $\alpha 3$ a phage was detected. These results suggest that an error-prone repair mechanism is lacking in this species.

\section{INTRODUCTION}

Vibrio sp. JT2 is a halotolerant collagenolytic Gram-negative bacterium which was isolated from cured hides and is associated with leather decay (Thomson et al., 1972). The strain is an interesting one in that it carries a cryptic prophage, $\alpha 3 \mathrm{a}$, inducible by $N$-methyl- $N^{\prime}$-nitro- $N$ nitrosoguanidine (MNNG) and mitomycin $\mathrm{C}(\mathrm{MC})$ but not by UV irradiation. It has been proposed that a defective enzyme necessary for prophage excision and/or vegetative phage development, produced by the cryptic prophage, can be reverted or suppressed by mutagens and lead to prophage induction (Thomson \& Woods, 1974). Such a proposal would be supported by the finding that whereas MNNG and MC are able to induce mutations in Vibrio JT2, UV irradiation is not.

Mutations resulting from treatment with UV (Drake \& Baltz, 1976; Walker \& Dobson, 1979) are caused by the induction of a highly error-prone repair system, one of the responses of the socalled SOS system (Miller, 1983; Radman, 1975; Walker, 1984; Witkin, 1976). MNNG is a mutagen whose action is due to alkylation of DNA largely independent of the rec $A$ gene product in Escherichia coli (Gichner \& Veleminsky, 1982; Iishi \& Kondo, 1975) and thus organisms lacking the SOS repair system are readily MNNG mutable. MC is thought to cause mutations by the repair of MC-induced cross-linkages in DNA, although the exact mechanism appears to be unclear (Boyce \& Howard-Flanders, 1964). the present study was aimed at investigating the mutagenic actions of MNNG, MC and UV light on Vibrio JT2. As UV reactivation of UVirradiated phage (Weigle reactivation; Weigle, 1953) depends on the induction of an active error-prone repair system (Witkin, 1976), this process was also investigated in Vibrio JT2.

According to the proposal outlined above the presence or absence of the cryptic prophage should have no effect on the mutagenic action of these three agents. To verify this, a derivative of JT2, JTc39, which had been cured of its prophage, was used as a control.

\section{METHODS}

Bacterial and phage strains. The Vibrio strains used were all derivatives of Vibrio sp. JT2, a prototrophic, halotolerant, collagenolytic bacterium isolated from cured hides (Thomson et al., 1972, 1981; Robb et al., 1980). The auxotrophic mutants for use in reversion studies were JT-21 Trp ${ }^{-}$and JT-28 Ile-, which were isolated by

† Present address: CSIR Laboratory for Molecular and Cell Biology, University of the Witwatersrand, 1 Jan Smuts Avenue, Johannesburg 2001, South Africa.

$\ddagger$ Present address: Department of Microbiology, University of Cape Town, Rondebosch 7700, South Africa.

Abbreviations: MC, mitomycin C; MNNG, $N$-methyl- $N^{\prime}$-nitro- $N$-nitrosoguanidine. 

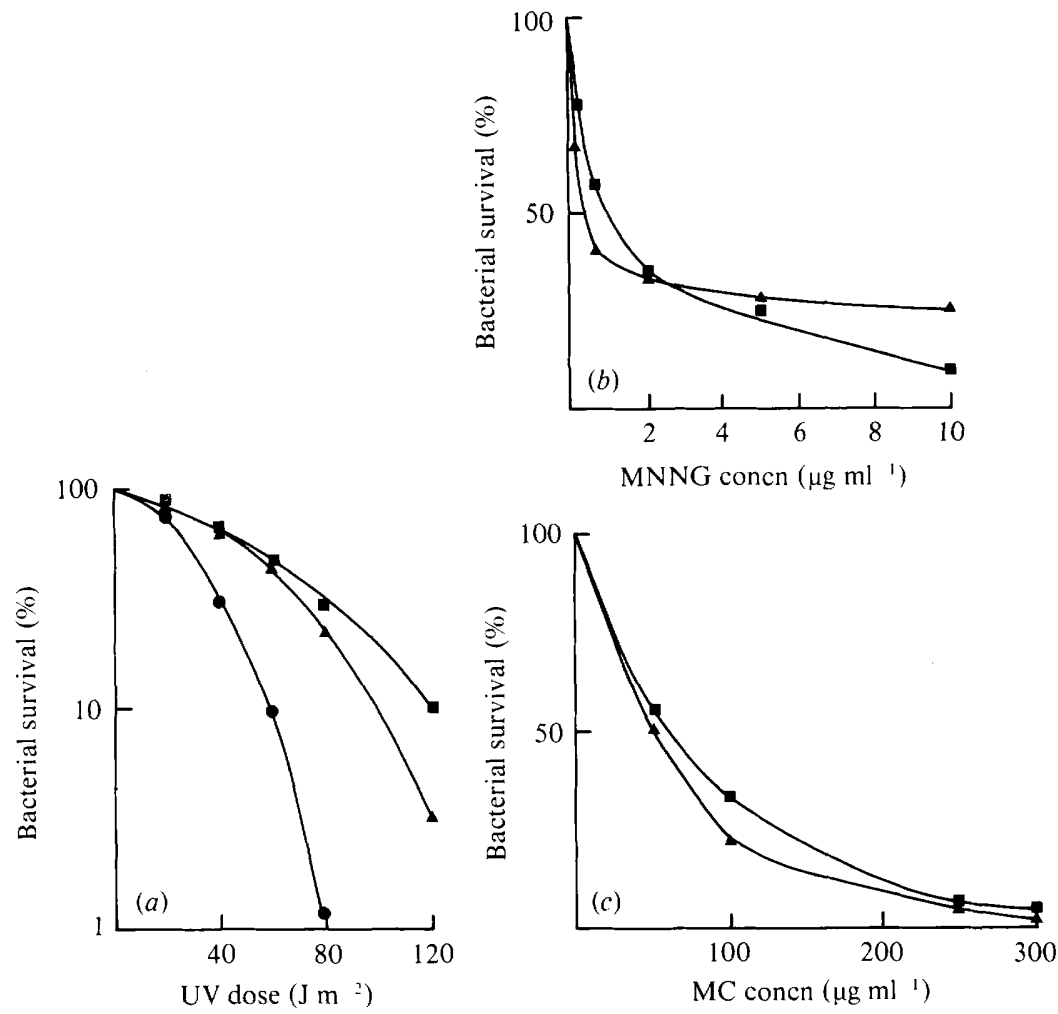

Fig. 1. Sensitivities of strains to (a) UV irradiation, $(b)$ MNNG and (c) MC treatment as described in the text. Data represent the means of three experiments. O, E. coli $\mathrm{C} 600 ; \mathbf{\square}$, Vibrio JT2; $\mathbf{\Delta}$, Vibrio JTc39.

MNNG mutagenesis of JT2. Strain JTc39 is a derivative of JT2 cured of its cryptic $\alpha 3$ a prophage by treatment with MNNG followed by colony hybridization with ${ }^{32} \mathrm{P}$-labelled $\alpha 3 \mathrm{a}$ phage DNA (unpublished results). Escherichia coli $\mathrm{C} 600$ was used for comparative purposes. The bacteriophage was $\alpha 3$ a isolated after spontaneous liberation by JT2 (Thomson \& Woods, 1974).

Media and chemicals. Specific media for Vibrio JT2 were used and Luria broth was supplemented with $0.4 \mathrm{M}$ NaCl, (LSB; Thomson \& Woods, 1974; Woods \& Thomson, 1975). All amino acids and MC were obtained from Sigma, and MNNG from Koch-Light.

$U V, M N N G$ and $M C$ treatment. For survival determination, exponentially growing cultures were washed and resuspended in $0.4 \mathrm{M}-\mathrm{NaCl}$ (Vibrio) or $0.145 \mathrm{M}-\mathrm{NaCl}$ (E. coli). Samples to be tested for UV sensitivity were irradiated in $10 \mathrm{ml}$ portions in a $100 \mathrm{~mm}$ glass Petri dish with constant stirring at increasing doses using a model UVS-54 Mineralight shortwave UV $254 \mathrm{~nm}$ lamp. Appropriate dilutions were plated immediately. All manipulations were carried out in the dark to eliminate photoreactivation. UV doses were measured using a Blakray UV meter model J-225 (Ultra-violet Products, Inc.). Samples of Vibrio to be tested for MNNG and MC sensitivity were resuspended in LSB with increasing concentrations of the DNA-damaging agent and incubated at $37^{\circ} \mathrm{C}$ for $15 \mathrm{~min}$ prior to plating. For the isolation of mutants, survivors were plated either on LSB agar containing rifampicin $\left(3 \mu \mathrm{g} \mathrm{ml}^{-1}\right)$ or nalidixic acid $\left(0 \cdot 2 \mu \mathrm{g} \mathrm{ml}^{-1}\right)$ or, in the case of reversion of JT-21 and JT-28 to prototrophy, on minimal medium.

Weigle reactivation of $\alpha 3$ a phage. Phage $\alpha 3 \mathrm{a}$, prepared as before (Thomson \& Woods, 1974) was UV irradiated and plated on Vibrio JT-21 cells irradiated with increasing doses of UV light according to the method of Weigle (1953). Phage titres were determined as before (Thomson \& Woods, 1974).

\section{RESULTS}

Sensitivity of Vibrio to $U V, M N N G$ and $M C$

Exponentially growing Vibrio JT2 and JTc39 were both more resistant to UV irradiation than repair-proficient E. coli 600 (Fig. 1a). Thus, if this Vibrio species lacks an error-prone repair 

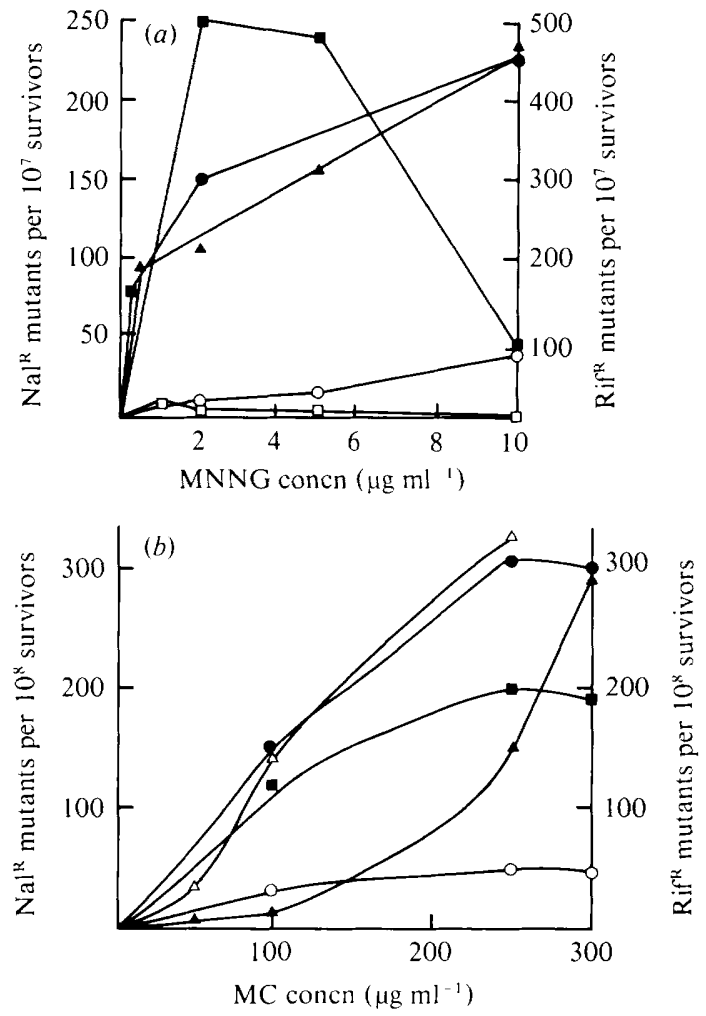

Fig. 2. Mutagenesis of Vibrio JT2 and JTc39 by MNNG and MC. Exponential-phase cells were incubated in medium containing increasing concentrations of MNNG or MC as described in the text. Data represent the means of three experiments. (a) MNNG mutagenesis. 0,0 JT2 resistant to nalidixic acid $\left(0,0.2 \mu \mathrm{g} \mathrm{ml}^{-1} ; \bigcirc, 2 \mu \mathrm{g} \mathrm{ml}^{-1}\right) ; \square, \square, \mathrm{JTc} 39$ resistant to nalidixic acid $\left(\square, 0.2 \mu \mathrm{g} \mathrm{ml}^{-1}\right.$; $\left.\square, 2 \mu \mathrm{g} \mathrm{ml}^{-1}\right) ; \mathbf{A}$, JT2 resistant to rifampicin $\left(3 \mu \mathrm{g} \mathrm{ml}^{-1}\right)$. (b) MC mutagensis. $\boldsymbol{O}, \mathrm{O}, \mathrm{JT} 2$ resistant to naladixic acid $\left(\mathbf{O}, 0 \cdot 2 \mu \mathrm{g} \mathrm{ml}^{-1} ; \bigcirc, 2 \mu \mathrm{g} \mathrm{ml}^{-1}\right) ; \boldsymbol{\square}, \mathrm{JTc} 39$ resistant to nalidixic acid $\left(0 \cdot 2 \mu \mathrm{g} \mathrm{ml}^{-1}\right) ; \boldsymbol{\Delta}, \triangle$, JT2 resistant to rifampicin $\left(\Lambda, 3 \mu \mathrm{g} \mathrm{ml}^{-1}: \triangle, 1 \cdot 5 \mu \mathrm{g} \mathrm{ml}^{-1}\right)$.

system, it must have other efficient UV repair systems. The sensitivity of JT2 and JTc39 to MNNG and MC were investigated in order to determine the conditions to be used for mutagenesis studies (Fig. $1 b, c$ ).

\section{Mutability of Vibrio}

Exposure of prototrophic JT2 and JTc39 to MNNG and MC resulted in the isolation of Rif ${ }^{\mathrm{R}}$ and $\mathrm{Nal}^{\mathrm{R}}$ mutants (Fig. 2), while treatment of JT-21 Trp- and JT-28 $\mathrm{Ile}^{-}$yielded prototrophic revertants (Table 1). The optimal MNNG concentration for the isolation of mutants of JTc39 resistant to $0 \cdot 2 \mu \mathrm{g}$ nalidixic acid $\mathrm{ml}^{-1}$ was $2-5 \mu \mathrm{g} \mathrm{ml}^{-1}$, which corresponded to a survival frequency of about $35 \%$, whereas that for JT2 (at least $10 \mu \mathrm{g} \mathrm{ml}^{-1}$ ) corresponded to a survival frequency of less than $10 \%$. Very few mutants of either strain resistant to $2 \mu \mathrm{g}$ nalidixic acid $\mathrm{ml}^{-1}$ were isolated. Whereas Rif ${ }^{\mathrm{R}}$ mutants of JT2 were readily isolated, no Rif ${ }^{\mathrm{R}}$ mutants of $\mathrm{JTc} 39$ were found (Fig $2 a$ ). When MC was used as a mutagen (Fig. $2 b$ ), JT2 mutants resistant to $0 \cdot 2 \mu \mathrm{g}$ nalidixic acid $\mathrm{ml}^{-1}$, and to a lesser extent to $2 \mu \mathrm{g} \mathrm{ml}^{-1}$, were isolated as well as mutants resistant to 1.5 and $3 \mu \mathrm{g}$ rifampicin $\mathrm{ml}^{-1}$, but the mutation frequency was an order of magnitude lower than for MNNG. Nal ${ }^{\mathrm{R}}$ mutants of JTc39 were also isolated at low frequencies. Revertants of both JT-21 and JT-28 to $\mathrm{Trp}^{+}$and $\mathrm{Ile}^{+}$respectively were isolated after treatment with MNNG although it was apparent that the trp mutation reverted at a considerably greater frequency than ile (Table 1). Reversion by MC was not investigated. 


\section{Table 1. MNNG-induced reversion of auxotrophic mutants}

Data are the means of three experiments. Frequencies shown as $<0 \cdot 1$ represent examples where no revertants were isolated.

\begin{tabular}{|c|c|c|c|c|}
\hline \multirow[b]{2}{*}{$\begin{array}{l}\text { Percentage } \\
\text { survival }\end{array}$} & \multicolumn{2}{|c|}{$\begin{array}{l}\text { No. of } \mathrm{Trp}^{+} \\
\text {revertants of JT-21 } \\
\text { per } 10^{8} \text { c.f.u. after }\end{array}$} & \multicolumn{2}{|c|}{$\begin{array}{l}\text { No. of } \mathrm{Ile}^{+} \\
\text {revertants of JT- } 28 \\
\text { per } 10^{8} \text { c.f.u. after }\end{array}$} \\
\hline & $72 \mathrm{~h}$ & $120 \mathrm{~h}$ & $72 \mathrm{~h}$ & $120 \mathrm{~h}$ \\
\hline 100 & $<0 \cdot 1$ & $0 \cdot 1$ & $<0.1$ & $<0.1$ \\
\hline 24 & 21 & 25 & 0.6 & 0.8 \\
\hline 1 & 520 & 55 & 13 & 25 \\
\hline $0 \cdot 1$ & 141 & 150 & $1 \cdot 3$ & 2 \\
\hline
\end{tabular}

Table 2. UV mutagenesis of Vibrio strains

Data are the means of three experiments. Plates were counted after 48 and $72 \mathrm{~h}$ but were checked again after $120 \mathrm{~h}$ with no change in the mutation frequences.

\begin{tabular}{|c|c|c|c|c|c|}
\hline Strain & $\begin{array}{l}\text { Percentage } \\
\text { survival }\end{array}$ & $\begin{array}{l}\text { No. of JT2 } \\
\text { Rif }{ }^{\mathrm{R}} \text { mutants } \\
\text { per } 10^{7} \text { c.f.u. }\end{array}$ & $\begin{array}{l}\text { No, of JT2 } \\
\mathrm{Nal}^{\mathrm{R}} \text { mutants } \\
\text { per } 10^{7} \text { c.f.u. }\end{array}$ & $\begin{array}{l}\text { No. of JT- } 21 \\
\text { Trp }^{+} \text {revertants } \\
\text { per } 10^{7} \text { c.f.u. }\end{array}$ & $\begin{array}{l}\text { No. of JT- } 28 \\
\text { Ile }^{+} \text {revertants } \\
\text { per } 10^{7} \text { c.f.u. }\end{array}$ \\
\hline \multirow[t]{6}{*}{ JT2, JT-21 and JT-28 } & 100 & $0 \cdot 4$ & $0 \cdot 4$ & $0 \cdot 1$ & $<0.1$ \\
\hline & 63 & $<0.4$ & ND & $0 \cdot 1$ & ND \\
\hline & 50 & $<0.5$ & $0 \cdot 5$ & ND & $0 \cdot 1$ \\
\hline & 10 & 0.1 & 0.6 & $<0.5$ & $0 \cdot 1$ \\
\hline & 3 & ND & $<0 \cdot 3$ & ND & $<0 \cdot 3$ \\
\hline & $0 \cdot 1$ & $<0.5$ & $<0.4$ & $0 \cdot 1$ & ND \\
\hline \multirow[t]{3}{*}{ JTc39 } & 100 & $<0.4$ & $<0.5$ & & \\
\hline & 61 & $<0.4$ & $<0.4$ & & \\
\hline & $0 \cdot 1$ & $<0 \cdot 3$ & $<0.3$ & & \\
\hline
\end{tabular}

Table 3. Growth of $U V$ irradiated phage $\alpha 3 a$ in $U V$-treated $J T 2$

Data are the means of three experiments. There was no significant difference in results between incubation temperatures of $30^{\circ} \mathrm{C}$ and $37^{\circ} \mathrm{C}$.

$\begin{array}{ccc}\begin{array}{c}\text { Percentage } \\ \text { survival } \\ \text { of JT2 }\end{array} & \begin{array}{c}\text { Time of } \\ \text { post-irradiation } \\ \text { incubation of JT2 }\end{array} & \begin{array}{c}\text { Relative } \\ \text { survival } \\ \text { (h) }\end{array} \\ 100 & 0 & \text { of } \alpha 3 \mathrm{a}^{*} \\ & 2 & 0 \cdot 40 \\ & 4 & 0 \cdot 40 \\ 95 & 6 & 0 \cdot 45 \\ & 0 & 0 \cdot 50 \\ & 2 & 0 \cdot 40 \\ 90 & 4 & 0 \cdot 40 \\ & 6 & 0 \cdot 46 \\ & 0 & 0 \cdot 30 \\ 70 & 2 & 0 \cdot 30 \\ & 4 & 0 \cdot 35 \\ & 6 & 0 \cdot 30 \\ & 0 & 0 \cdot 28 \\ & 2 & 0 \cdot 35 \\ & 4 & 0 \cdot 35 \\ & 6 & 0 \cdot 40 \\ & 0 & 0 \cdot 35\end{array}$

* Survival frequencies are given relative to the p.f.u. of unirradiated $\alpha 3$ a plated on unirradiated JT2 without post-irradiation incubation. 
Strains JT2, JT-21, JT-28 and JTc39 were exposed to increasing doses of UV radiation to give decreasing survival frequencies, but no increase in the number of mutants isolated was found for any of the four markers tested (Table 2). This was also the case when sublethal concentrations of caffeine ( 1 and $2 \mathrm{mg} \mathrm{ml}^{-1}$ ), a known inhibitor of excision repair in prokaryotes (Timson, 1977), was included in the selective media (data not shown). [In E. coli, UV-induced mutagenesis increases in excision repair deficient mutants, but as no such mutants exist in this Vibrio species caffeine was used instead.]

\section{Weigle reactivation}

To determine whether UV-irradiated phage $\alpha 3$ a could be reactivated by a UV-inducible repair system in JT2, the phage was irradiated to give a survival frequency when plated on unirradiated $\mathrm{JT} 2$ of $50 \%$. Exponentially growing cells of JT2 were irradiated with low doses of UV light to give survival frequencies of $70-98 \%$. Irradiated cells were washed and incubated in LSB for $1-5 \mathrm{~h}$ at $30^{\circ} \mathrm{C}$ and $37^{\circ} \mathrm{C}$ to allow for possible induction of repair proteins. No reactivation of irradiated phage $\alpha 3 \mathrm{a}$ was found under any of the conditions used (Table 3 ).

\section{DISCUSSION}

Both Vibrio JT2 and its cured derivative JTc39 were more resistant to UV-irradiation than repair-proficient $E$. coli $\mathrm{C} 600$. This is in contrast to most bacteria that lack a form of postreplicative repair, which are generally more sensitive to UV-induced lethality.

Both JT2 and JTc39 were readily mutated by MNNG and MC for the markers selected, although in general JTc39 yielded fewer mutants. The significance of this has not yet been determined. As expected, MNNG was a far more potent mutagen than MC. Conversely no increase above the spontaneous mutation frequency was found after UV-irradiation of JT2 or $\mathrm{JTc} 39$. That this reflects the absence in these strains of a UV-inducible error-prone postreplicative repair system was supported by the absence of UV-inducible phage reactivation (Weigle reactivation).

It has been proposed that since many bacterial species which lack error-prone repair are competent for DNA-mediated transformation, competency is not compatible with error-prone repair (Sicard, 1983; Yasbin, 1977). This correlation has been questioned, as Proteus mirabilis and Salmonella typhimurium appear to be deficient in this repair system (Hofemeister et al., 1979; Walker, 1978). However, both these species possess at least some elements of the SOS response (Walker, 1984). It would therefore be of interest to investigate whether this Vibrio species has any SOS-like responses.

This work was supported by a research grant from the Council for Scientific and Industrial Research.

\section{REFERENCES}

Boyce, R. P. \& Howard-Flanders, P. (1964). Genetic control of DNA breakdown and repair in $E$. coli $\mathrm{K}-12$ treated with mitomycin $\mathrm{C}$ or ultraviolet light. Zeitschrift für Vererbungslehre 95, 345-350.

Drake, J. \& BalTZ, R. H. (1976). The biochemistry of mutagenesis. Annual Review of Biochemistry 45, 127.

Gichner, T. \& Veleminsky, J. (1982). Genetic effects of $N$-methyl- $N^{\prime}$-nitro- $N$-nitrosoguanidine and its homologs. Mutation Research 99, 129-242.

Hofemeister, J., KohleR, H. \& Fillipov, V. D. (1979). DNA repair in Proteus mirabilis. VI. Plasmid (R46)-mediated recovery and ultraviolet mutagenesis. Molecular and General Genetics 176, 265-273.

IIsHI, Y. \& Kondo, S. (1975). Comparative analysis of deletion and base change mutabilities of Escherichia coli B strains differing in repair capacities (wild type, urra ${ }^{-}$, uvr $B^{-}$, pol $A^{-}, \operatorname{rec} A^{-}$) by various mutagens. Mutation Research 27, 27-44.

MILLER, J. (1983). Mutational specificity in bacteria. Annual Review of Genetics 17, 215-283.

RADMAN, M. (1975). SOS repair hypothesis. Phenomenology of an inducible DNA repair which is accompanied by mutagenesis. In Molecular Mechanisms for Repair of DNA, pp. 355-367. Edited by P. C. Hanawalt \& R. S. Setlow. New York: Plenum.

Roвb, S. M., RobB, F. T. \& Woods, D. R. (1980). Physiological and morphological characteristics of stationary phase Vibrio cells able to support phage growth. Journal of General Microbiology 119, 405412 .

SICARD, N. (1983). Possible correlation between transformability and deficiency in error-prone repair. Journal of Bacteriology 154, 995-997. 
Thomson, J. A. \& Woods, D. R. (1974). Bacteriophages and cryptic lysogeny in Achromobacter. Journal of General Virology 22, 153-157.

Thomson, J. A., Woods, D. R. \& Welton, R. L. (1972). Collagenolytic activity of aerobic halophiles from hides. Journal of General Microbiology 70, 315319.

Thomson, J. A., Hendson, M. \& Magnes, R. M. (1981). Mutagenesis by insertion of drug resistance transposon $\operatorname{Tn} 7$ into a Vibrio species. Journal of Bacteriology 148, 374-378.

Timson, J. (1977). Caffein. Mutation Research 47, 1-52.

WALKER, G. C. (1978). Inducible reactivation and mutagenesis of UV-irradiated bacteriophage P22 in Salmonella typhimurium LT2 containing plasmid pKM101. Journal of Bacteriology 135, 415-421.

WALKER, G. C. (1984). Mutagenesis and inducible responses to deoxyribonucleic acid damage in Escherichia coli. Microbiological Reviews 48, 60-93.
Walker, G. C. \& Dobson, P. P. (1979). Mutagenesis and repair deficiencies of Escherichia coli umuC mutants are suppressed by plasmid pK M101. Molecular and General Genetics 172, 17-24.

Weigle, J. J. (1953). Induction of mutations in a bacterial virus. Proceedings of the National Academy of Sciences of the United States of America 39, 628636.

WitKIN, E. M. (1976). Ultraviolet mutagenesis and inducible DNA repair in Escherichia coli. Bacteriological Reviews 40, 869-907.

Woods, D. R. \& Thomson, J. A. (1975). Unstable generalized transduction in Achromobacter. Journal of General Microbiology 88, 86-92.

YASBIN, R. E. (1977). DNA repair in Bacillus subtilis. II. Activation of the inducible system in competent bacteria. Molecular and General Genetics 153, 214 225 . 